\title{
December Morning in Jamaica
}

JANE M. TURNBULL, HAMPTON, MALVERN, JAMAICA

(The story of a few southern relatives of Canadian birds seen through the eyes of a Manitoban)

At last the "Norther" has blown itself out. Sun and birds have come back. One week of overcast skies, with a penetrating, cold wind and the thermometer falling to the fifties at nights, seems an eternity in Jamaica. Now we are back to normal, so that this morning's after breakfast walk on the drive was truly a glad recognition after long absence.

To begin with, the drive in this circumstances is not a sweeping avenue of stately trees, as the word ordinarily suggests. It is a half-mile stretch of winding, rock road skirting, a high hill. It has, therefore, a steep, heavily wooded slope on one side of it, and a narrow grassy valley below it on the other. The road is separated from the little valley and the hills beyond by a dry-stone parapet, which takes on the loveliest hues of soft rose and blue in the evening light, but like everything else in the morning, is damp and fresh with dew until the sun can reach it. This is a private road with little traffic besides the family cars, sometimes a higgler bringing in a basket of produce on her head, or a woodsman taking out two or three bamboo poles in the same way. With the exception of the garden boy returning from the post office in the village, there was no one but myself on the drive.

The usual sounds and sights seemed clearer and more precious after a week of emptiness. Even the floating flight of the turkey vulture (John Crow, cathartes aura) on motionless, outspread wings offered a point of interest, for his featherless head and the lack lustre of his plumage were invisible and forgotten in the grace and strength of his flight. The flycatchers were about their business too, from the bold but handsome loggerhead (tolmarchus caudifascistus) to Little Tom Fool (myiarchus barbirostris), called "sad." Strangely enough this morning, not a nightingale (northern mockingbird, mimus polyglottos) was to be seen, nor a humming-bird, two of the most dependable companions of the road. I did hear the peculiar whirr of the long feathers of a streamer-tail (Doctor Bird, trochilus polytmus), but before I located him, the raucous, scolding voice of a big Jamaican woodpecker (centurus radiolatus) commanded my attention to the topmost branch of a trumpet tree. And all the while a tiresome Hopping. Dick (white-chinned thrush, turdus aurantius) was doing his self-appointed best to frighten away all and sundry by sounding the alarm that there was a traveller on the drive. However, the sunshine was so gratefully warm and the sparkling trees so tempting that even the shyest, most colorful birds ignored him.

And so I stood and watched a yellow-back finch (loxipasser anoxanthus), tailor-made with his black head and breast piece, the yellowish green of his back accented by bright yellow epaulettes. A little further along, it was a squarely built little Tody (todus todus) that flashed his light waistcoat and scarlet necktie toward ine, and then turned his vivid green back, indistinguishable from the leaves of the hibiscus where he went to hide. Because of the tiny dash of red at his throat, he is called Robin Redbreast in Jamaica. At another place my eyes caught a flutter in the dark heart of a shining shrub. It proved to be a northern yellow-throat (geothlypis trichas), determined to get rid of the damp on his feathers. There he was, billing and ruffling, twisting this way and that, shaking his head as if he would loosen his black mask itself. Then again, I stood stalk still by a gully overgrown with bamboo, and watched a sprightly, slender thrush or thrasher, with cinnamon brown upperparts and bold brown markings on his creamy underparts, taking a few pickings from underneath a dead leaf on the road. Lastly, when the walk was nearly 
over, a briéf, brilliant pattern of black and orange flashed against the grey bole of a logwood. I waited, to be absolutely sure that he was real, as he flickered hither and yon. Yes, it was an American redstart (Butterfly Bird, setophaga ruticilla). His bright trimmings toned in perfectly with the red of the cup-like flowers of a nearby spathodea. My glance fell to the foreground just beyond the stone wall. A little clump of deep blue forget-me-nots in the grass provided an artist's contrasts. It was for only a matter of seconds, since the redstart did not linger.

I continued toward the house. Half a dozen ground doves (columbigallina passerina) flew up from the lawn as I approached. I looked at my watch. I had spent exactly one hour on the drive.

\section{Spring Migration}

\section{Arthur Ward, Swift Current}

Migration, again was greatly disturbed by the unusual cool cloudy wet weather. Nearly every species arriving before the leaves of trees were out. Large flocks of Horned Larks, covering many miles of territory were observed during the first week of March. In our district, the Slatecoloured Junco and the Tree Sparrow were not seen in the usual numbers, but the Olive-backed Thrush was seen to have greatly increased. The Sandhill Cranes were well represented. One flock passing over, going northwest, was estimated to be over six hundred. Of the rare birds to pass through here with a light increase was the Northern Water Thrush. I caught and banded a male and a female of this species.

Coots are as plentiful as last year, but there is a slightly diminishing number of Horned Grebes. Two of these were observed just practising a repeated performance of last year in our yard, trying to lay a foundation on the branch of a willow tree edging the dugout and level with the water. They would carry sticks of dead wood, a foot long and lay them on the branch, then dive for a mouthful of dead vegetable matter. If the stick was too long they both took a hold. After a day's work they moved over to another slough, just like they did last year-must have been the same pair.

\section{Birds in Sweden}

\section{E. K. Forsberg, Riceton, Sask.}

Following are a few noies about birds I saw at Vato, Sweden, from December 1952 to February 1953:

Talgoxen (or Chickadee). About the size of our Chickadee. Some have black and white heads with yellow on back and breast. Others are blue on the head and yellow on back and breast.

Skatan (Magpie)-similar to ours only smaller.

Krakan (Crow)-grey on breast and smaller than ours.

Hackspetan (Woodpecker)-more colorful and larger than ours.

Another bird was grey with rust breast, about the size of a young Robin. I did not find out its name. This bird and the Talgoxen were quite tame and used to feed in a little bird house every morning by our window.

I might add that everyone in Sweden loves and feeds the birds. 